\title{
Pre-treatment of pectinase and amylase on production of banana based wine
}

\author{
Md. AleEM ZaKeR*, K.A. SYed and R.S. HARKAL
}

Department of Food Science and Technology, M.I.P College of Food Technology, Aundha, HINGOLI (M.S.) INDIA

(Email: zakermohd.ft@gmail.com)

*Author for Correspondence

Research chronicle : Received : 05.08.2014; Revised : 30.10.2014; Accepted : 16.11.2014

\begin{abstract}
SUMMARY :
Pretreatment of pectinase and amylase to hydrolyze pectin and starch of banana must prior to its use to produce a banana wine product. The Synergetic activity of this enzyme enhances hydrolyses of complex carbohydrate. A threefold increase in amount of extracted juice were obtained after incubating with 0.5 per cent $(\mathrm{w} / \mathrm{w})$ of commercial pectinolytic enzyme at $40^{\circ} \mathrm{C}$ for one hour, followed by treating with 0.05 per cent $(\mathrm{w} / \mathrm{w})$ of amylase at $50^{\circ} \mathrm{C}$ for three hours. A $15-17$ per cent increase in total soluble sugar in extracted juice was achieved, respectively. After this enzyme treated must and non enzyme treated banana must was diluted with four volume of water and then fermented by yeast produce banana wine. The pretreatment of banana with enzyme before fermentation resulted in higher level of reducing sugar than control during fermentation. The clarification of enzyme treated banana wine was three fold higher than that of control at 30 days of fermentation were observed. The concentration of total soluble sugar and alcohol in the enzyme treated and control have no significance difference were observed.
\end{abstract}

KEY WORDS : Banana must, Pectinase, Amylase Clarification, Total soluble sugar

How to cite this paper : Zaker, Md. Aleem, Syed, K.A. and Harkal, R.S. (2014). Pre-treatment of pectinase and amylase on production of banana based wine. Internat. J. Proc. \& Post Harvest Technol., 5 (2) : 145-150. 